\title{
(6) OPEN ACCESS \\ Lack of a significant change in caffeine metabolism in underweight children as determined by the caffeine breath test
}

\author{
K A Oshikoya, ${ }^{1}{ }^{1}$ H Sammons, ${ }^{1}$ K Smith, ${ }^{3}$ I Choonara ${ }^{1}$
}

${ }^{1}$ Academic Division of Child Health, Graduate Entry Medical School in Derby, University of Nottingham, Derby, UK ${ }^{2}$ Department of Pharmacology, Lagos State University College of Medicine, Ikeja, Lagos, Nigeria

${ }^{3}$ Clinical Physiology Department Graduate Entry Medical School in Derby, University of Nottingham, Derby, UK

\section{Correspondence to} Dr Kazeem Adeola Oshikoya, Department of Pharmacology, Lagos State University College of Medicine, Ikeja, Lagos 234, Nigeria;

kazeemoshikoya@ymail.com.

Received 8 December 2014 Revised 11 March 2015 Accepted 12 March 2015 Published Online First 20 April 2015

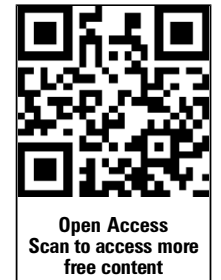

CrossMark

To cite: Oshikoya $K A_{\text {, }}$ Sammons H, Smith K, et al. Arch Dis Child

2015;100:689-693

\section{ABSTRACT}

Objective Limited data from pharmacokinetic studies in underweight and severely malnourished children have indicated an impaired activity of their hepatic enzymes. We used the caffeine breath test to assess the metabolising activity of cytochrome P450 1A2 (CYP1A2) enzyme in underweight children.

Methods Underweight children from the paediatric outpatient clinic, Lagos State University Teaching Hospital, Ikeja in Nigeria, were studied. After an overnight fast, 15 underweight children took $3 \mathrm{mg} / \mathrm{kg}$ labelled caffeine orally. Breath samples were collected in duplicate at $-20,-10$ and $-1 \mathrm{~min}$ and at $15 \mathrm{~min}$ intervals for $2 \mathrm{~h}$. The mean cumulative per cent dose recovered (CPDR) of labelled caffeine in the expired carbon dioxide was determined over the study period. This was repeated after 2-6 weeks of nutritional rehabilitation.

Results The mean areas under the enrichment-time curve before and after nutritional rehabilitation were $0.539 \pm 0.320$ and $0.620 \pm 0.322$ atom per cent excess minute, respectively. The difference between the two values was not statistically significant $(p=0.528)$. The mean CPDR in the exhaled carbon dioxide of the underweight children over a period of $2 \mathrm{~h}$ was 7.56 $\pm 4.01 \%$ and $7.95 \pm 3.68 \%$ before and after nutritional rehabilitation, respectively, and there was no significant difference in the mean values ( $p=0.603)$.

Conclusions The metabolism of caffeine was not significantly affected in underweight children compared with after 2-6 weeks of nutritional rehabilitation. This suggests that hepatic CYP1A2-metabolising activity was not significantly impaired in underweight children.

\section{INTRODUCTION}

Globally, an estimated 15\% (99 million) of children aged $<5$ years were underweight in $2012 .{ }^{1}$ The latest WHO nutrition survey, expressed in weight-for-age z-score (WAZ), in South-East Asia has reported moderate underweight (WAZ $<-2$ to -3 ) among $29 \%$ of children aged $<5$ years and severe underweight (WAZ $<-3$ ) in $12 \%$ of the same population of children. ${ }^{2}$ The most common reason for being underweight is malnutrition due to lack of adequate food calories and nutrients. ${ }^{3}$

The risk of death from the four major childhood infectious diseases (pneumonia, diarrhoea, measles and malaria) is significantly higher for underweight children. ${ }^{4}$ The risk for multiple infections is higher in underweight than in well-nourished children. Drug therapy, especially the use of anti-infective agents, is therefore important in this group.

\section{What is already known on this topic?}

Drug metabolism may be impaired in malnourished children including those who were underweight.

- Breath samples are stable and require no special preservation before analysis.

- The caffeine breath test can be used to study CYP1A2 activity.

\section{What this study adds?}

Metabolism of caffeine in underweight children was not significantly impaired.

- Hepatic CYP1A2 was not significantly impaired in underweight children.

- The caffeine breath test is a feasible method for studying drug metabolism in children in low resource settings.

The most widely used method of classifying malnutrition is the Wellcome Trust Working Party classification based on physical signs and anthropometric parameters of the patient. ${ }^{5}$ The percentage of body weight deficit in the presence or absence of oedema serves as the criterion for classification. It recognises an underweight child as having 60\%$80 \%$ of the expected weight in the absence of pedal oedema.

Drug metabolism in underweight children has been poorly studied ${ }^{6}$ and its clinical relevance with regards to drug dosing in this group of children has not been investigated. Limited data from pharmacokinetic studies in this group have indicated a decrease in the total clearance of antipyrine ${ }^{7}$ and quinine ${ }^{8}$ as well as increased half-life of paracetamol. ${ }^{9}$ Other pharmacokinetic studies comparing severe malnutrition (marasmus, marasmic-kwashiorkor and kwashiorkor) with underweight children showed that drug disposition is impaired in severely malnourished children. ${ }^{6}$ These findings would suggest a need for drug dose modification in underweight and severely malnourished children.

The caffeine breath test (CBT) has been used to study both drug interactions and effect of disease on drug metabolism in children. ${ }^{10} 11$ The test involves oral administration of a non-radioactive stable isotope $\left({ }^{13} \mathrm{C}\right.$ on the 3 -methyl group of caffeine). The labelled caffeine undergoes 3-N-demethylation 
which is a cytochrome P450 (CYP1A2)-dependent reaction. After the 3-N-demethylation, the labelled methyl group enters the one carbon pool and converts to formaldehyde, formate and bicarbonate. ${ }^{12}$ The bicarbonate is finally exhaled as carbon dioxide. The cumulative per cent labelled-caffeine dose exhaled as carbon dioxide over a 2 -h period is the gold standard for measuring CYP1A2 activity. ${ }^{14-16}$

In a recent study, we have used the CBT to demonstrate a significant decrease in the metabolising activity of CYP1A2 in severely malnourished children. ${ }^{17}$ In order to gain more insight into the effect of underweight malnutrition on hepatic metabolism of medicines, we used the CBT to assess the metabolising activity of CYP1A2 in a group of underweight children, before and after nutritional rehabilitation.

\section{METHODS}

Fifteen underweight children were recruited from the paediatric outpatient department of Lagos State University Teaching Hospital, Ikeja. A sample size of 12 participants was considered appropriate for this study based on $90 \%$ power calculation and assuming a $2 \%$ difference in the mean \pm SD score of the $2 \mathrm{~h}$ cumulative per cent of ${ }^{13} \mathrm{C}$ from the baseline to $2-6$ weeks of restudy after nutritional rehabilitation, at a $5 \%$ level of significance, using previous CBT studies as a reference. ${ }^{10} \quad 11 \quad 18$ However, provision for dropout and withdrawal necessitated the use of a sample size of 15 participants. Inclusion criteria included participants in a stable clinical state, age $\geq 3$ years, informed consent from the parent and assent from a participant aged $\geq 6$ years. Exclusion criteria included participants with HIV or tuberculosis infection, on regular medications, and having hearing impairment, cerebral palsy or elevated blood pressure. Other exclusion criteria were persistent abnormal renal or liver function tests, persistent signs and symptoms of primary cardiovascular, respiratory or gastrointestinal disease.

Underweight malnutrition was diagnosed as a patient with $60 \%-80 \%$ of the expected weight without pedal oedema. ${ }^{5}$ Participants were first studied when underweight and after nutritional rehabilitation to attain over $80 \%$ of the expected weight for age.

Body weight and height of each subject were measured as described in our study in severely malnourished children. ${ }^{17}$ All the participants avoided caffeinated products for $20 \mathrm{~h}$ and fasted overnight prior to the CBT. All the CBTs were commenced at 9:00. Casilan, calculated as one-twelfth of the recommended dietary allowance of calories, ${ }^{19}$ was ingested at 8:30 before caffeine administration because of ethical issues surrounding fasting of the underweight children. Casilan is bland powder milk, rich in protein but very low in fat and carbohydrate. ${ }^{19}$ The subjects remain seated for $10 \mathrm{~min}$ prior to the collection of the first breath sample. Participants were kept busy by the lead researcher throughout the whole test so as to minimise physical activity which can affect endogenous carbon dioxide production and result in dilution of the labelled carbon dioxide. ${ }^{10} 11$

Participants consumed $3 \mathrm{mg} / \mathrm{kg}$ labelled caffeine made into solution at 9:00. The caffeine was obtained in powder form from Cambridge Isotope Laboratories (Cambridge, Massachusetts, USA). Each sample of the caffeine was dissolved in $10 \mathrm{~mL}$ of clean water. Non-sugary squash was added to the mixture to mask the bitter taste of caffeine. The container was washed with $20 \mathrm{~mL}$ of water, which was also consumed by the participants. Breath samples were collected in pairs while the subjects expired normally at $-20,-10$ and $-1 \mathrm{~min}$ prior to caffeine (predose samples) and after caffeine ingestion (postdose samples) every 15 min over $2 \mathrm{~h}$. Breath samples were collected into an Exetainer bottle by asking each child to blow via a straw. The vital signs of the participants were recorded and monitored throughout the study.

Participants were restudied after adequate nutritional rehabilitation for 2-6 weeks, thus serving as their own controls. Casilan and caffeine administration, as well as breath sample collection, was according to the protocol described for severely malnourished children after undergoing nutritional rehabilitation. ${ }^{17}$ The breath samples were stored in the Exetainer bottles for 12 weeks before transport by air for analysis at the Clinical Physiology Laboratory of the Graduate Entry Medical School of the University of Nottingham, UK.

The ${ }^{13} \mathrm{C}$-enrichment in the breath samples was determined by continuous-flow isotope ratio mass spectrometry ${ }^{20}$ using a SerCon-Automated Breath Carbon Analyser (CF-IRMS; Europa Hydra; SerCon, Crewe, UK). The details of the analytical procedure are as documented in our previous study. ${ }^{17}$

CYP1A2-metabolising activity was determined using the cumulative ${ }^{13} \mathrm{CO}_{2}$ in the expired breath samples collected over $2 \mathrm{~h}$ as a gold standard. The cumulative ${ }^{13} \mathrm{CO}_{2}$ output was determined as an average of the ${ }^{13} \mathrm{C}$-enrichment for the eight breath samples exhaled over $2 \mathrm{~h}$ multiplied by the average carbon dioxide output $\left(\mathrm{VCO}_{2}\right)$ over the study period $(300 \mathrm{mmol} / \mathrm{body}$ surface area per hour). ${ }^{21} 22$ The result was expressed as a percentage of the caffeine dose administered.

The Ethics Committee of Lagos State University Teaching Hospital, Ikeja, approved the study. Parents gave their informed consent, and subjects who were aged $\geq 6$ years gave their assent.

The participants were compared when underweight and after nutritional rehabilitation, using a Student's paired t test at 5\% level of significance.

\section{RESULTS}

Analysis of the demographics and anthropometric parameters of the 15 underweight children showed that their mean age was 7.6 \pm 2.9 years. Their mean weight significantly increased from 17.9 $\pm 5.6 \mathrm{~kg}$ (before nutritional rehabilitation) to $21.4 \pm 6.8 \mathrm{~kg}$ (after nutritional rehabilitation; Student's paired t test, $\mathrm{p}<0.005)$. All the children had reached at least $80 \%$ of their expected weight before the second breath test (table 1). Their mean height significantly increased from $115.4 \pm 16.3 \mathrm{~cm}$ (before nutritional rehabilitation) to $116.5 \pm 16.2 \mathrm{~cm}$ (after nutritional rehabilitation; Student's paired t test, $\mathrm{p}<0.005)$. They were restudied after a mean period of 3.7 weeks following nutritional rehabilitation.

The mean areas under the enrichment-time curve before and after nutritional rehabilitation were $0.539 \pm 0.320$ and 0.620 \pm 0.322 atom per cent excess minute, respectively. The difference between the two mean values was not statistically significant (Student's paired t test, $\mathrm{p}=0.528$ ).

The average cumulative per cent doses recovered (CPDR) in the exhaled $\mathrm{CO}_{2}$ over a period of $2 \mathrm{~h}$ of the underweight children are shown in table 1 . The mean CPDR was $7.56 \pm 4.01 \%$ before and $7.95 \pm 3.68 \%$ after nutritional rehabilitation, and there was no significant difference in the mean values (Student's paired t test, $\mathrm{p}=0.603$ ).

The individual cumulative per cent labelled caffeine dose exhaled as $\mathrm{CO}_{2}$ in a period of $2 \mathrm{~h}$ by each underweight child both before and after nutritional rehabilitation is presented in figure 1 . There was greater interindividual variation seen before rather than after nutritional rehabilitation.

\section{DISCUSSION}

In the present study, underweight children were studied before and after nutritional rehabilitation. Nutritional rehabilitation for 2-6 weeks enabled the underweight children to attain the 
Table 1 Average cumulative per cent ${ }^{13} \mathrm{C}$-dose in the exhaled $2-\mathrm{h} \mathrm{CO}_{2}$ of underweight children, before and after nutritional rehabilitation

\begin{tabular}{|c|c|c|c|c|c|c|c|c|c|}
\hline \multirow[b]{2}{*}{$\begin{array}{l}\text { Subjects } \\
\text { (n) }\end{array}$} & \multicolumn{3}{|c|}{ Prenutritional rehabilitation } & \multirow[b]{2}{*}{$\begin{array}{l}\text { Degree of } \\
\text { underweight } \\
\text { malnutrition } \\
\text { relative to the } \\
\text { expected normal } \\
\text { weight for age }(\%) \dagger^{=}\end{array}$} & \multirow[b]{2}{*}{$\begin{array}{l}\text { Time interval } \\
\text { between study } \\
\text { I and II } \\
\text { (weeks) }\end{array}$} & \multicolumn{3}{|c|}{ Postnutritional rehabilitation } & \multirow[b]{2}{*}{$\begin{array}{l}\text { Change after } \\
\text { nutritional } \\
\text { rehabilitation } \\
(\mathrm{B}-\mathrm{A} ; \%)\end{array}$} \\
\hline & $\begin{array}{l}\text { Labelled } \mathrm{CO}_{2} \\
\text { output over the } \\
2 \mathrm{~h} \text { study period } \\
\text { (mmol/h) }\end{array}$ & $\begin{array}{l}\text { Average per cent } \\
{ }^{13} \mathrm{CO}_{2} \text { exhaled } \\
\text { (study I) }\end{array}$ & $\begin{array}{l}\text { Cumulative per cent } \\
{ }^{13} \mathrm{C} \text {-dose (caffeine) } \\
\text { recovered }^{*} \text { in the } \\
2 \mathrm{~h} \mathrm{CO}{ }_{2} \\
\text { exhaled (\%; A) }\end{array}$ & & & $\begin{array}{l}\text { Labelled } \mathrm{CO}_{2} \\
\text { output over the } \\
2 \mathrm{~h} \text { study } \\
\text { period } \\
(\mathrm{mmol} / \mathrm{h})\end{array}$ & $\begin{array}{l}\text { Average } \\
\text { per cent } \\
{ }^{13} \mathrm{CO}_{2} \\
\text { exhaled } \\
\text { (study II) }\end{array}$ & $\begin{array}{l}\text { Cumulative per cent } \\
{ }^{13} \mathrm{C} \text {-dose (caffeine) } \\
\text { recovered }{ }^{*} \text { in the } \\
2 \mathrm{~h} \mathrm{CO}{ }_{2} \\
\text { exhaled (\%; B) }\end{array}$ & \\
\hline 1 & 251.44 & 0.04230 & 10.64 & 79.3 & 2 & 232.82 & 0.05708 & 13.29 & $2.65(24.9)$ \\
\hline 2 & 283.53 & 0.01391 & 3.94 & 66.3 & 2 & 251.34 & 0.02519 & 6.33 & $2.39(60.7)$ \\
\hline 3 & 254.84 & 0.04083 & 10.41 & 76.5 & 3 & 234.51 & 0.05352 & 12.55 & $2.14(20.6)$ \\
\hline 4 & 234.57 & 0.03194 & 7.49 & 77.8 & 3 & 224.37 & 0.05611 & 11.34 & 3.85 (51.4) \\
\hline 5 & 263.35 & 0.04455 & 11.73 & 66.7 & 3 & 233.85 & 0.05029 & 11.76 & $0.03(0.3)$ \\
\hline 6 & 244.56 & 0.00332 & 0.81 & 68.4 & 3 & 217.67 & 0.00910 & 1.98 & $1.17(14.4)$ \\
\hline 7 & 248.78 & 0.00557 & 1.39 & 65.0 & 3 & 217.29 & 0.00893 & 1.94 & $0.55(39.6)$ \\
\hline 8 & 196.46 & 0.03276 & 6.44 & 75.6 & 2 & 185.02 & 0.02886 & 5.34 & $-1.10(-17.1)$ \\
\hline 9 & 214.02 & 0.01971 & 4.22 & 62.7 & 4 & 184.58 & 0.02714 & 5.01 & $0.79(18.7)$ \\
\hline 10 & 170.55 & 0.05025 & 8.57 & 67.7 & 6 & 153.92 & 0.03742 & 5.76 & $-2.81(-32.9)$ \\
\hline 11 & 157.12 & 0.10210 & 16.04 & 76.9 & 2 & 150.75 & 0.05645 & 8.51 & $-7.53(-46.9)$ \\
\hline 12 & 158.98 & 0.05382 & 8.56 & 76.9 & 4 & 149.35 & 0.06501 & 9.71 & $1.15(13.4)$ \\
\hline 13 & 165.26 & 0.05325 & 8.80 & 63.9 & 6 & 142.11 & 0.05397 & 7.67 & $-1.13(-12.8)$ \\
\hline 14 & 152.37 & 0.03678 & 5.60 & 68.8 & 6 & 137.90 & 0.04880 & 6.73 & $1.13(20.2)$ \\
\hline 15 & 159.86 & 0.05460 & 8.73 & 60.8 & 6 & 139.10 & 0.07268 & 10.11 & $1.38(15.8)$ \\
\hline Mean+SD & & & $7.56 \pm 4.01$ * & $70.2 \pm 6.3$ & $3.7 \pm 1.6$ & & & $7.95 \pm 3.68^{*}$ & \\
\hline
\end{tabular}

${ }^{*} \mathrm{p}<0.005 ;$ Student's $\mathrm{t}$ test.

tExpected normal weight is the estimated weight (w) for age using the methods in Nelson's Textbook of Pediatrics: (age in months+9)/2 for children aged 3-12 months; ((age in years $\times 2)+8)$ for children aged 1-6 years and ((age in years $\times 7.5) / 2)$ for children aged $7-12$ years. ${ }^{23}$ 


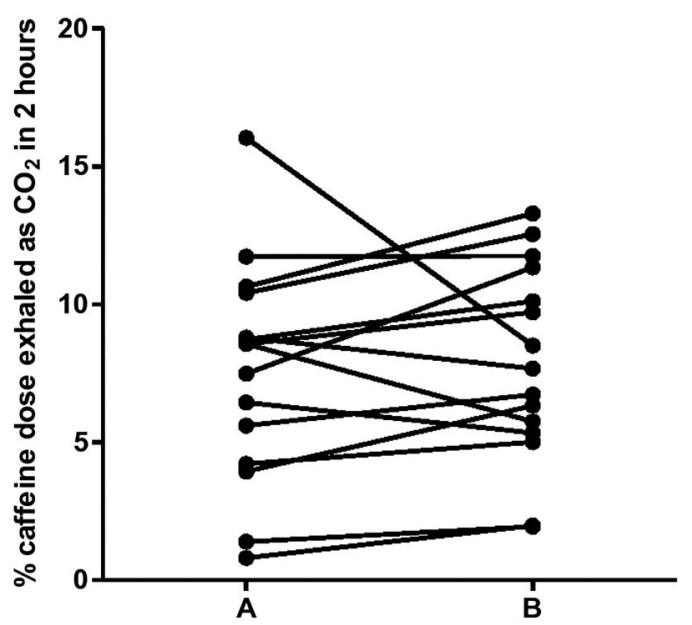

$A=$ Pre-nutritional rehabilitation

$\mathrm{B}=$ Pos t-nutritional rehabilitation

Figure 1 Individual cumulative per cent $13 \mathrm{C}$-dose recovery in $2 \mathrm{~h}$ for each underweight child, both before and after nutritional rehabilitation, expressed as a percentage of the oral caffeine dose administered.

expected weight-for-height of well-nourished children before they were restudied, thus serving as normal weight controls. We have demonstrated no significant difference in labelled $\mathrm{CO}_{2}$ exhaled over $2 \mathrm{~h}$. This suggests that the metabolism of labelled caffeine was not significantly affected in children when they were underweight compared with when they had attained at least $80 \%$ normal weight after nutritional rehabilitation.

A limitation of our study is that the children were studied immediately after nutritional rehabilitation. It is possible that hepatic enzyme recovery significantly lagged behind nutritional recovery. However, our findings are consistent with those of Tranvouez et $\mathrm{al}^{24}$ who determined the plasma clearance (CL) of antipyrine (a drug, ie, partially metabolised by CYP1A2) in underweight adults and showed no significant change after nutritional rehabilitation. ${ }^{24}$

Three other studies, in contrast, have shown decreased CL of different drugs in underweight patients. Specifically, antipyrine CL was decreased in underweight adults, ${ }^{25}$ while the CLs of acetylsalicylic acid and penicillin decreased in underweight children. ${ }^{26} 27$ Different types of CYP450 enzymes are responsible for the metabolism of caffeine and acetylsalicylic acid, while penicillin is usually eliminated without undergoing hepatic metabolism. Acetylsalicylic acid is metabolised by CYP3A4, while caffeine is predominantly metabolised by CYP1A2. Variation in the activity of the metabolising enzymes may account for the differences in the disposition of caffeine and other drugs in underweight children.

The present results of underweight children are in contrast to those of severely malnourished children. ${ }^{17}$ CYP1A2 enzyme activity was significantly impaired in severely malnourished children with marasmus, marasmic-kwashiorkor or kwashiorkor. ${ }^{17}$ It is important therefore to be aware that malnutrition is a spectrum of nutritional disorders and its effect on drug metabolism will vary with the type of malnutrition and the accompanying physiological changes. The mechanism involved in the altered CYP1A2 activity and decreased caffeine metabolism in severe malnutrition remains poorly understood. It has been postulated that impairment in drug metabolism in children with marasmus may be partly related to an adaptation to insufficient energy intake, resulting in reduced total microsomal haeme, phospholipids and flavin adenine dinucleotide levels, all of which are necessary for microsomal drug metabolism. ${ }^{28}$ Altered drug metabolism in children with marasmic-kwashiorkor has been linked to substantial changes in the quantities of microsomal membrane proteins, particularly the CYP450. ${ }^{29} 30$

Impairment of drug metabolism in children with kwashiorkor has been attributed to maladaptation to nutritional deprivation, which includes hepatic fatty infiltration, rough endoplasmic reticulum and mitochondria deformity and reduced peroxisomes. ${ }^{31}$

CYP1A2 is a major metabolic pathway for caffeine, theophylline, naproxen, haloperidol and the antidepressants duloxetine and fluvoxamine. ${ }^{32}$ It is also a contributory metabolic pathway for many other drugs. ${ }^{32}$ The findings from our study suggest that dose adjustment is not necessary for underweight children who are receiving caffeine, theophylline, haloperidol, naproxen, duloxetine or fluvoxamine. It is important, however, to recognise that our findings are only relevant for drugs where CYP1A2 is a major metabolic pathway. The effect of being underweight needs to be studied separately for each of the different metabolic pathways.

In conclusion, the CBT has demonstrated no significant change in the metabolism of caffeine in underweight children. This suggests that the doses of medicines that are primarily metabolised by hepatic CYP1A2 do not need to be modified in underweight children.

Contributors KAO conceived and designed the study, collected and analysed the samples, performed the data analysis and wrote the initial and final draft of the manuscript; $\mathrm{HS}$ and IC contributed to the conception and design of the study, reviewed the data analysis, edited and approved the final draft of the manuscript; KS contributed to the sample and data analyses and reviewed the initial draft of the manuscript.

Funding KAO was, at the time of this research, a postgraduate research student at the University of Nottingham, UK. He was jointly sponsored for the postgraduate education by the Lagos State Government and Lagos State University.

Competing interests None.

Patient consent Obtained.

Ethics approval Research and Ethics Committee of LASUTH.

Provenance and peer review Not commissioned; externally peer reviewed.

Open Access This is an Open Access article distributed in accordance with the Creative Commons Attribution Non Commercial (CC BY-NC 4.0) license, which permits others to distribute, remix, adapt, build upon this work non-commercially, and license their derivative works on different terms, provided the original work is properly cited and the use is non-commercial. See: http://creativecommons.org/ licenses/by-nc/4.0/

\section{REFERENCES}

1 United Nations Children's Fund, World Health Organization, The World Bank, UNICEF-WHO-World Bank Joint Child Malnutrition Estimates. 2013. http://www. who.int/nutgrowthdb/jme_unicef_who_wb.pdf (accessed 5 Dec 2013).

2 World Health Organization. Report of the sixth meeting of South-East Asia Nutrition Research-cum-Action Network. Yangon, Myanmar, 6-8 February 2001. http://www. searo.who.int/LinkFiles/Nutrition_for_Health_and_Development_nut-151.pdf (accessed 12 Dec 2010).

3 Müller 0, Krawinkel M. Malnutrition and health in developing countries. Canadian Med Assoc J 2005;173:279-86.

4 Caulfield LE, de Onis M, Blossner M, et al. Undernutrition as an underlying cause of child deaths associated with diarrhea, pneumonia, malaria, and measles. Am J Clin Nutr 2004;80:193-8.

5 Wellcome Trust Working Party. Classification of infantile malnutrition. Lancet 1970;2:302-3.

6 Oshikoya KA, Sammons HM, Choonara I. A systematic review of pharmacokinetics studies in children with protein-energy malnutrition. Eur J Clin Pharmacol 2010;66:1025-35.

7 Homeida M, Karrar ZA, Roberts CJC. Drug metabolism in malnourished children: a study with antipyrine. Arch Dis Child 1979;54:299-302.

8 Pussard $\mathrm{E}$, Barennes $\mathrm{H}$, Daouda $\mathrm{H}$, et al. Quinine disposition in globally malnourished children with cerebral malaria. Clin Pharmacol Ther 1999;65:500-10.

9 Mehta S, Nain CK, Yada VD, et al. Disposition of acetaminophen in children with protein calorie malnutrition. Int J Clin Pharmacol Ther Toxicol 1985;23:311-15.

10 Parker AC, Pritchard P, Preston T, et al. Lack of inhibitory effect of cimetidine on caffeine metabolism in children using the caffeine breath test. Br J Clin Pharmacol 1997:43:467-70 
11 Parker AC, Preston $T$, Heaf $D$, et al. Inhibition of caffeine metabolism by ciprofloxacin in children with cystic fibrosis as measured by the caffeine breath test. Br J Clin Pharmacol 1994;38:573-6.

12 Lambert GH, Schoeller DA, Katoke AN, et al. The effect of age, gender, and sexual maturation on the caffeine breath test. Dev Pharmacol Ther 1986;9:375-88.

13 Butler MA, Iwasaki M, Guengerich FP, et al. Human cytochrome P-450PA (P-450IA2), the phenacetin 0-deethylase, is primarily responsible for the hepatic 3-demethylation of caffeine and $\mathrm{N}$-oxidation of carcinogenic arylamines. Proc Natl Acad Sci USA 1989;86:7696-700.

14 Kalow W, Tang B. The use of caffeine for enzyme assays: a critical apparaisal. Clin Pharmacol Ther 1993;53:503-14.

15 Park GJ, Katelaris $\mathrm{PH}$, Jones $\mathrm{DB}$, et al. Validity of the ${ }^{13} \mathrm{C}$-caffeine breath test as a non-invasive, quantitative test of liver function. Hepatology 2003;38:1227-36.

16 Kotake AN, Schoeller DA, Lambert $\mathrm{GH}$, et al. The caffeine $\mathrm{CO}_{2}$ breath test: dose response and route of $\mathrm{N}$-demethylation in smokers and non-smokers. Clin Pharmacol Ther 1982;32:261-9.

17 Oshikoya KA, Smith K, Sammons $\mathrm{H}$, et al. Decreased metabolism of ${ }^{13} \mathrm{C}$-caffeine via hepatic CYP1A2 in marasmus and kwashiorkor based on breath test. J Basic Clin Physiol Pharmacol 2015;26:105-13.

18 Parker AC, Pritchard P, Preston T, et al. Induction of CYP1A2 activity by carbamazepine in children using the caffeine breath test. Br J Clin Pharmacol 1998;45:176-8.

19 British national formulary for children. London, UK: BMJ Publishing Group Ltd, RPS Publishing, and RCPCH Publications Ltd, 2006.

20 Preston T, McMillan DC. Rapid sample throughput for biomedical stable isotope tracer studies. Biomed Environ Mass Spectrom 1988;16:229-35.

21 Shreeve VW, Cerasi E, Luft R. Metabolism of [2-14C] pyruvate in normal, acromegalic and HGH-treated human subjects. Acta Endocrinol (Copenh) 1970;65:155-69.
22 Haycock G, Schwartz G, Wisotsky G. Geometric method for measuring body surface area: a height-weight formula validated in infants, children and adults. J Pediatr 1978;93:62-6.

23 Needlman RD. The first year. In: Behrman RE, Kliegman RM, Jenson HB, eds. Nelson Textbook of Pediatrics. 17th edn. Philadelphia: WB Saunders, 2004:31.

24 Tranvouez JL, Lerebours $\mathrm{E}$, Chretien $\mathrm{P}$, et al. Hepatic antipyrine metabolism in malnourished patients: influence of the type of malnutrition and course after nutritional rehabilitation. Am J Clin Nutr 1985;41:1257-64.

25 Krishnaswamy K, Naidu AN. Microsomal enzymes in malnutrition as determined by plasma half-life of antipyrine. Br Med J 1977;1:538-40.

26 Lares-Asseff I, Flores-Pérez J, Juárez-Olguín $\mathrm{H}$, et al. Influence of nutritional status on the pharmacokinetics of acetylsalicylic acid and its metabolites in children with autoimmune disease. Am J Clin Nutr 1999;69:318-24.

27 Bolme $\mathrm{P}$, Eriksson M, Paalzow L, et al. Malnutrition and pharmacokinetics of penicillin in Ethiopian children. Pharmacol Toxicol 1995;76:259-62.

28 Rumack BH, Holtzman J, Chase HP. Hepatic drug metabolism and protein malnutrition. J Pharmacol Exp Ther 1973;186:441-6.

29 Hayes JR, Mgbodile MU, Campbell TC. Effect of protein deficiency on the inducibility of the hepatic microsomal drug metabolizing enzyme system-I. Effect on substrate interaction with cytochrome P-450. Biochem Pharmacol 1973:22:1005-14.

30 Thabrew MI. Liver microsomal membrane lipid composition in marasmic-kwashiorkor. Life Sci 1983;32:671-5.

31 Brooks SE, Doherty FJ, Golden MH. Peroxisomes and the hepatic pathology of childhood malnutrition. West Indian Med J 1994;43:15-17.

32 de Wildt SN, Tibboel D, Leeder JS. Drug metabolism for the paediatrician. Arch Dis Child. 2014;99:1137-42. 